\title{
FAKTOR - FAKTOR YANG MEMPENGARUHI KEMANDIRIAN ANAK RETARDASI MENTAL SEDANG DI SDLB 1 NEGERI DENPASAR
}

\section{FACTORS THAT INFLUENCE THE CHILDREN OF MENTAL RETARDATION CHILDREN ARE IN SDLB 1 DENPASAR}

\author{
Niken Ayu Merna Eka Sari1, I Nyoman Asdi Winata2
}

\begin{abstract}
ABSTRAK
Pendahuluan: Anak dikatakan sehat apabila pertumbuhan dan perkembangannya sesuai dengan tahapan umur dan tidak mengalami gangguan penyakit secara fisik maupun mental. Namun seiring dengan perkembangan zaman, banyak ditemukan masalah gangguan kesehatan terkait dengan perkembangan mental. Salah satu gangguan kesehatan yang cenderung meningkat dan menjadi masalah baik di Negeri maju atau berkembang saat ini adalah retardasi mental. Penelitian ini bertujuan untuk mengetahui factor - factor yang mempengaruhi tingkat kemandirian perawatan diri pada anak retardasi mental ringan di SDLB 1 Negeri Denpasar tahun 2016. Metode: pendekatan yang digunakan dalam penelitian ini adalah pendekatan kuantitatif penelitian deskriptif (descriptive research). Besar sampel dalam penelitian ini sejumlah 53 anak dengan tehnik pengambilan sampel non probability sampling jenis "Purposive sampling. Hasil: berdasarkan karakteristik responden didapatkan sebagian besar anak berumur 10 tahun sejumlah $22,6 \%$, pendidikan sebagian besar SD 60,4\%, jenis kelamin sebagian besar 75,5\%, dan sebagian besar anak ke-2 yaitu sebesar 45,3\%. Uji statistic yang digunakan adalah korelasi kontingensi didapatkan umur dan tingkat pendidikan memiliki nilai 0.03 dan 0.01.Diskusi: hal ini menunjukkan bahwa usia dan tingkat pendidikan sangat mempengaruhi tingkat kemandirian anak retardasi mental sedang.
\end{abstract}

Kata Kunci : Tingkat Kemandirian, Anak Retardasi Mental

\section{ABSTRACT}

Children are said to be healthy if the growth and development in accordance with the stages of age and do not experience diseases physically and mentally.But along with the development of the times, many health problems are found related to mental development.One of the health disorders that tends to increase and become a problem in both the developed and developing countries today is mental retardation. This study aims to determine the factors that affect the level of selfsufficiency of self-care in children with mild mental retardation in SDLB 1 Denpasar.The approach used in this research is quantitative approach descriptive research.Sample size in this research are 53 children with sampling technique non probability sampling purposive sampling.Based on the characteristics of the respondents, most of the children aged 10 years are $22.6 \%$, most of the primary education is $60.4 \%$, gender is $75.5 \%$ and most of them are $45.3 \%$. The statistic test used is contingency correlation obtained age and educational level has value 0.03 
and 0.01 .The results of this study indicate that the age and level of education greatly affects the level of independence of children with moderate mental retardation.

\section{Keyword : Level of Independence, Child Mental Retardation}

\section{PENDAHULUAN}

Keadaan individu yang normal belum tentu dimiliki anak saat dilahirkan. Beberapa diantaranya mempunyai keterbatasan, baik secara fisik maupun psikis yang telah dialami sejak awal masa perkembangan. Kondisi anak yang sehat adalah harapan setiap keluarga. Anak dikatakan sehat apabila pertumbuhan dan perkembangannya sesuai dengan tahapan umur dan tidak mengalami gangguan penyakit secara fisik maupun mental. Namun seiring dengan perkembangan zaman, banyak ditemukan masalah gangguan kesehatan terkait dengan perkembangan mental. Salah satu gangguan kesehatan yang cenderung meningkat dan menjadi masalah baik di Negeri maju atau berkembang saat ini adalah retardasi mental (BKKBN, 2010).

Kejadian retardasi mental menurut WHO tahun (2013) dalam Sari (2014) diperkirakan 1 per 800 sampai 1 per 1000 kelahiran di Amerika Serikat terjadi pada semua etnis dan semua lapisan ekonomi. Kejadian retardasi mental di Indonesia tahun 2013 sebanyak 1-3 \% dari jumlah penduduk Indonesia menderita retardasi mental, yang berarti dari 1000 penduduk diperkirakan 30 penduduk menderita retardasi mental dengan kriteria retardasi mental ringan $80 \%$, retardasi mental sedang $12 \%$, retardasi mental sangat berat $8 \%$ (Depkes RI, 2013 dalam Sari, 2014). Insiden tertinggi didapatkan pada kelompok usia sekolah, dengan puncak umur 1014 tahun (Soetjiningsih, 2012). Pada data pokok sekolah luar biasa (SLB) tahun 2013, dilihat dari kelompok usia sekolah jumlah penduduk di Indonesia yang menyandang kelainan adalah 48.100 .548 orang jadi estimasi penduduk di Indonesia yang menyandang retardasi mental adalah 962.011.

Data dari Dinas Sosial Provinsi Bali menunjukkan jumlah penyandang disabilitas sebanyak 20.085 orang termasuk didalamnya penyandang retardasi mental. Jumlah tersebut tersebar di 9 kabupaten di Bali, sekitar $6,4 \%$ berada di wilayah Denpasar. Sedangkan data dari Dinas Pendidikan Pemuda dan Olahraga Provinsi Bali tahun 2013/2014, jumlah penyandang disabilitas di sekolah luar biasa (SLB) sebanyak 1.689 anak yang tersebar di masing-masing kabupaten. Jumlah terbanyak ditemukan di wilayah Denpasar yaitu $501(29,7 \%)$ anak yang tersebar di 4 SLB di Denpasar. Jumlah total 501 anak sebanyak 276 anak $(55,1 \%)$ merupakan penyandang retardasi mental ringan dan sedang. Persentase ini merupakan jumlah kecacatan terbanyak diantara kecacatan lainnya (Disdikpora, 2013).

Hasil studi pendahuluan yang peneliti lakukan pada bulan Maret 2016 di SDLB C Negeri Denpasar, jumlah anak retardasi mental yang bersekolah di SDLB 1 Negeri Denpasar sebanyak 61 orang anak dengan retardasi mental ringan. Berdasarkan hasil wawancara dari 10 orang tua siswa dengan retardasi mental untuk kemandirian anak dalam perawatan diri 8 anak dibantu dalam kebersihan mandi, 5 anak jarang gosok gigi, 7 anak kebersihan gigi kurang, 6 anak tidak rapi dalam berpakaian, 5 anak masih disuapi bila akan makan. 8 anak tidak cuci tangan sebelum makan. Selain itu dari hasil wawancara sebanyak 2 orang tua berusaha untuk melatih dengan teratur dan memberikan kebebasan dan tanggung jawab 
kepada anaknya untuk melakukan perawatan diri. Hasil observasi terhadap 10 anak retadardasi mental terkait kemandirian perawatan diri didapatkan sebanyak 8 orang $(80 \%)$ belum bisa sikat gigi sendiri, 4 orang $(40 \%)$ ketika buang air kesil masih diarahkan dan dibantu oleh guru, sebanyak 6 orang $(60 \%)$ masih dibantu menuangkan air kedalam gelas dan sebanyak 8 orang $(80 \%)$ belum bisa memasang tali sepatu.

Retardasi Mental ditandai dengan defisit dengan fungsi adaptif, seperti bidang komunikasi, merawat dirinya sendiri, home living, keterampilan sosial, interpersonal, dan keterampilan akademik. Tanda-tanda umum dari mental retardation adalah kesulitan dalam berkomunikasi, kesulitan dalam mengurus diri sendiri atau rumah, kesulitan membina relasi sosial atau personal, rendahnya kemampuan akademis, kesehatan dan keselamatan (Maslim, 2010). Kemandirian perawatan diri adalah keterampilan diri untuk mengurus atau menolong diri sendiri dalam kehidupan sehari-hari sehingga tidak tergantung dengan orang lain. Anakanak berkebutuhan khusus biasanya kurang mampu dalam melakukan perawatan dirinya karena adanya ketidakmampuan dalam melakukan interaksi, komunikasi, dan prilaku (Janiwarti, 2010).

Berdasarkan uraian tersebut maka peneliti tertarik untuk melakukan penelitian tentang faktor - faktor yang mempengaruhi tingkat kemandirian perawatan diri pada anak retardasi mental di SDLB 1 Negeri Denpasar tahun 2017.

\section{BAHAN DAN METODE}

Metode yang digunakan dalam penelitian ini adalah metode deskriptif, dengan jenis studi korelasional. Pendekatan yang digunakan dalam penelitian ini adalah pendekatan kuantitatif penelitian deskriptif (descriptive research). Populasi dalam penelitian ini adalah semua orang tua dan anak retardasi mental ringan di SDLB 1 Negeri Denpasar sebanyak 61 orang. Sampel yang digunakan dalam penelitian ini sejumlah 53 orang, dengan kriteria inklusi orang tua bersedia menjadi responden, orang tua yang tinggal bersama anak retardasi mental.orang tua dengan anak retardasi mental ringan dan criteria eksklusi orang tua yang tidak hadir / sekolah selama penelitian dilakukan dan orang tua yang tidak mengasuh anak retardasi mental. Pengambilan sampel menggunakan tehnik non probability sampling jenis Purposive sampling. Penelitian ini dilaksanakan pada bulan 5 Desember sampai dengan 20 Februari 2017 di SDLB 1 Negeri Denpasar.

Analisis yang digunakan yaitu analisis univariat dan bivariat. Analisis univariat dimaksudkan untuk mengetahui distribusi dari variabel-variabel yang diamati sehingga dapat mengetahui gambaran tiap variabel pada penelitian ini adalah uji korelasi koefisien kontingensi karena data variabel bebas nominal sedangkan variabel terikat ordinal. Berdasarkan hasil uji ditentukan apakah hipotesa diterima atau ditolak. Penentuan hipotesa diterima atau ditolak adalah dengan membandingkan nilai probability yang didapatkan dari hasil pengujian dengan nilai signifikansi, pada penelitian ini tingkat signifikansi sebesar $95 \%$ sama dengan $\alpha 0,05$. 
HASIL

Tabel 1 Karakteristik Subjek Penelitian Berdasarkan Umur Di SLBC 1 Negeri Denpasar

\begin{tabular}{|c|c|c|c|c|c|}
\hline \multicolumn{6}{|c|}{ Umur } \\
\hline & & Frequency & Percent & $\begin{array}{c}\text { Valid } \\
\text { Percent }\end{array}$ & $\begin{array}{c}\text { Cumulative } \\
\text { Percent }\end{array}$ \\
\hline \multirow[t]{12}{*}{ Valid } & 6 & 1 & 1,9 & 1,9 & 1,9 \\
\hline & 7 & 3 & 5,7 & 5,7 & 7,5 \\
\hline & 8 & 1 & 1,9 & 1,9 & 9,4 \\
\hline & 9 & 4 & 7,5 & 7,5 & 17,0 \\
\hline & 10 & 12 & 22,6 & 22,6 & 39,6 \\
\hline & 11 & 4 & 7,5 & 7,5 & 47,2 \\
\hline & 12 & 8 & 15,1 & 15,1 & 62,3 \\
\hline & 13 & 8 & 15,1 & 15,1 & 77,4 \\
\hline & 14 & 5 & 9,4 & 9,4 & 86,8 \\
\hline & 15 & 4 & 7,5 & 7,5 & 94,3 \\
\hline & 16 & 3 & 5,7 & 5,7 & 100,0 \\
\hline & Total & 53 & $\overline{100,0}$ & 100,0 & \\
\hline
\end{tabular}

Berdasarkan tabel 1 di atas di dapatkan sebagian besar umur responden yaitu 10 thun sejumlah 12 anak $(22,6 \%)$ dan sebagian kecil berumur 6 dan 8 tahun yaitu masing-masing sejumlah 1 anak $(1,9 \%)$.

Tabel 2 Karakteristik Subjek Penelitian Berdasarkan Tingkat Pendidikan di SLBC 1 Negeri Denpasar

Pendidikan

\begin{tabular}{|c|c|c|c|c|c|}
\hline & & $\begin{array}{c}\text { Freq } \\
\text { uenc } \\
y\end{array}$ & Percent & $\begin{array}{c}\text { Valid } \\
\text { Percent }\end{array}$ & $\begin{array}{c}\text { Cumulative } \\
\text { Percent }\end{array}$ \\
\hline \multirow[t]{5}{*}{ Valid } & TK & 2 & 3,8 & 3,8 & 3,8 \\
\hline & $\overline{\mathrm{SD}}$ & 32 & 60,4 & 60,4 & 64,2 \\
\hline & SMP & 14 & 26,4 & 26,4 & $\overline{90,6}$ \\
\hline & $\overline{\text { SMA }}$ & 5 & 9,4 & 9,4 & 100,0 \\
\hline & Total & 53 & 100,0 & 100,0 & \\
\hline
\end{tabular}

Berdasarkan tabel 2 di atas di dapatkan sebagian besar tingkat pendidikan responden yaitu SD sejumlah 32 anak (60,4 \%) dan sebagian kecil tingkat pendidikan yaitu TK sejumlah 2 anak $(3,8 \%)$.

Tabel 3 Karakteristik Subjek Penelitian Berdasarkan Jenis Kelamin Di SLBC 1 Negeri Denpasar 
Berdasarkan tabel 3 di atas di dapatkan sebagian besar jenis kelamin responden yaitu laki - laki sejumlah 40 anak $(75,5 \%)$ dan sebagian kecil berjenis kelamin perempuan yaitu sejumlah 13 anak $(24,5 \%)$.

\section{JenisKelamin}

\begin{tabular}{|c|c|c|c|c|c|}
\hline & & Frequency & Percent & $\begin{array}{c}\text { Valid } \\
\text { Percent }\end{array}$ & $\begin{array}{c}\text { Cumulative } \\
\text { Percent }\end{array}$ \\
\hline \multirow[t]{3}{*}{ Valid } & Laki-laki & 40 & 75,5 & 75,5 & $\overline{75,5}$ \\
\hline & Perempuan & 13 & 24,5 & 24,5 & 100,0 \\
\hline & Total & 53 & 100,0 & 100,0 & \\
\hline
\end{tabular}

Tabel 4 Karakteristik Subjek Penelitian Berdasarkan Urutan Anak Di SLBC 1 Negeri Denpasar

AnakKe

\begin{tabular}{llrrrr}
\hline & & Frequency & Percent & $\begin{array}{c}\text { Valid } \\
\text { Percent }\end{array}$ & $\begin{array}{c}\text { Cumulative } \\
\text { Percent }\end{array}$ \\
\hline Valid & 1 & 18 & 34,0 & 34,0 & 34,0 \\
\cline { 2 - 6 } & 2 & 24 & 45,3 & 45,3 & 79,2 \\
\cline { 2 - 6 } & 3 & 7 & 13,2 & 13,2 & 92,5 \\
\cline { 2 - 6 } & 4 & 3 & 5,7 & 5,7 & 98,1 \\
\cline { 2 - 6 } & 6 & 1 & 1,9 & 1,9 & 100,0 \\
\cline { 2 - 6 } & Total & 53 & 100,0 & 100,0 & \\
\hline
\end{tabular}

Berdasarkan tabel 4 di atas di dapatkan sebagian besar responden merupakan anak ke-2 yaitu sejumlah 24 anak $(45,3 \%)$ dan sebagian kecil responden merupakan anak ke-6 yaitu sejumlah 1 anak (1,9\%).

Tabel 5 Tingkat Kemandirian Anak Di SLBC 1 Negeri Denpasar

Kemandirian

\begin{tabular}{llrrrr}
\hline & & $\begin{array}{c}\text { Frequenc } \\
\text { y }\end{array}$ & Percent & $\begin{array}{c}\text { Valid } \\
\text { Percent }\end{array}$ & $\begin{array}{c}\text { Cumulative } \\
\text { Percent }\end{array}$ \\
\hline Valid & Mandiri & 23 & 43,4 & 43,4 & 43,4 \\
\cline { 2 - 6 } & $\begin{array}{l}\text { Cukup } \\
\text { Mandiri }\end{array}$ & 21 & 39,6 & 39,6 & 83,0 \\
\cline { 2 - 6 } & Kurang & 9 & 17,0 & 17,0 & 100,0 \\
& Mandiri & & & & \\
\cline { 2 - 6 } & Total & 53 & 100,0 & 100,0 & \\
\hline
\end{tabular}

Berdasarkan tabel 4 di atas di dapatkan sebagian besar responden memiliki tingkat kemandirian mandiri yaitu sejumlah 23 anak (43,4 \%) dan sebagian kecil memiliki tingkat kemandirian kurang yaitu sejumlah 9 anak (17\%).

Tabel 6 Analisis Faktor Umur, Tingkat Pendidikan, Jenis Kelamin dan Urutan 
Anak Terhadap tingkat Kemandirian Anak Di SLBC 1 Negeri Denpasar

Likelihood Ratio Tests

\begin{tabular}{lcccc}
\hline Effect & $\begin{array}{l}\text { Model } \\
\text { Fitting } \\
\text { Criteria }\end{array}$ & & Likelihood Ratio Tests & \\
& $\begin{array}{c}\text {-2 Log } \\
\text { Likelihood } \\
\text { of Reduced } \\
\text { Model }\end{array}$ & Chi-Square & df & Sig. \\
& $\begin{array}{l}\text { M.540 } \\
\text { Intercept }\end{array}$ & 0,000 & 0 & \\
\hline Umur & 50,105 & 41,565 & 20 &, 003 \\
\hline $\begin{array}{l}\text { Pendidik } \\
\text { an }\end{array}$ & 32,301 & 23,760 & 6 &, 001 \\
\hline $\begin{array}{l}\text { JenisKel } \\
\text { amin }\end{array}$ & $14.085^{\text {b }}$ & 5,545 & 2 &, 063 \\
\hline AnakKe & 26,491 & 17,951 & 8 &, 022 \\
\hline
\end{tabular}

Berdasarkan tabel 5 di atas di dapatkan faktor umur dan tingkat pendidikan yang lebih berpengaruh terhadap tingkat kemandirian disbanding dengan factor jenis kelamin dan urutan anak dengan nilai signifikansi untuk faktor umur 0,003 dan tingkat pendidikan 0.001 .

\section{PEMBAHASAN}

Beberapa faktor yang mempengaruhi tingkat kemandirian anak dengan retardasi mental yaitu usia, jenis kelamin, urutan posisi anak dan tingkat pendidikan. Responden dalam penelitian ini memiliki rentang usia antara $10-16$ tahun. Hasil pengumpulan data menunjukkan semakin tinggi usia anak maka kemampuan anak dalam melaksanakan kebutuhan personal higyene semakin baik artinya anak semakin mandiri. Berdasarkan hasil tersebut menunjukkan bahwa faktor usia dan tingkat pendidikan berpengaruh terhadap tingkat kemandirian anak dengan retardasi mental sedang. Hal ini sesuai dengan teori Fadillah (2008) yang menyatakan bahwa semenjak kecil anak melihat dan mengeksplorasi lingkungannya atas kemampuannya sendiri dan melakukan apa yang menjadi kemauannya sendiri sehingga semakin bertambah usia anak, maka semakin tinggi tingkat kemandirian anak, karena anak belajar dan berproses dari lingkungannya dan dirinya sendiri serta, anak yang mendapatkan pendidikan akan bertindak lebih kreatif daripada anak yang tidak mendapatkan pendidikan. Pendidikan mengajarkan berbagai keterampilan dan pengembangan bagi dirinya, sehingga anak mampu belajar untuk mandiri.Hasil penelitian ini juga sejalan dengan penelitian Khalimatis Sa'diyah tahun 2016 di SMP LB ABC Pertiwi Mojokerto yang menyatakan bahwa usia merupakan salah satu faktor yang mempengaruhi kemandirian anak retardasi mental dalam melakukan personal hygiene. Semakin bertambah usia anak maka tingkat kemandirian anak semakin bagus.

Dalam penelitian ini faktor jenis kelamin dan urutan posisi anak tidak berpengaruh terhadap tingkat kemandirian anak dengan retardasi mental. Hasil penelitian ini berbeda dengan pendapat Fadillah (2008) yang menyatakan bahwa 
anak laki-laki biasanya lebih mandiri dari pada anak perempuan, karena anak lakilaki memiliki sifat yang agresif dominan dan maskulin dibandingkan anak perempuan yang sifatnya pasif, lemah, lembut dan feminism serta anak pertama sangat diharapkan sebagai pengganti orangtua dituntut untuk bertanggung jawab, sedangkan anak tengah memiliki peluang dari orangtua dan kakak-kakaknya lebih banyak bergantung dan tidak mandiri. Hasil tersebut juga tidak sejalan dengan penelitian Dyan Malida tahun 2011di SDLB Prof. Dr. Sri Soedewi Masjchun Sofwan, SH Jambi Tahun 2010yang menemukan adanya pengaruh factor jenis kelamin dan urutan posisi anak terhadap tingkat kemandirian anak retardasi mental. Hal tersebut kemungkinan disebabkan oleh karena perbedaan karakteristik responden. Dalam penelitian ini responden yang digunakan adalah anak retardasi mental sedang sedangkan pada penelitian Dyan Malida tahun 2011 respondennya adalah anak dengan retardasi mental ringan.Klasifikasi retardasi mental terbagi menjadi tiga yaitu retardasi mental ringan (Mild Mental Retardation), retardasi mental sedang (Moderate Mental Retardation) dan retardasi mental berat (Severe Mental Retardation). Dimana setiap klasifikasi memiliki karakteristik yang berbeda-beda. Untuk retardasi mental ringan beberapa gejalanya yaitu tidak memperlihatkan kelainan fisik, agak mengalami keterlambatan dalam belajar, mampu mandiri (mandi, makan, berpakaian) dan mengalami kesulitan dalam pelajaran sekolah sedangkan untuk retardasi mental sedang gejalanya mampu latih untuk melakukan keterampilan, terkadang menampakkan kelainan fisik berupa gejala bawaan, lambat dalam pengembangan pemahaman penggunaan bahasa dan ada yang agresif dan sikap bermusuh terhadap yang belum kenal. Dari gejala gejala tersebut jelas menunjukkan adanya perbedaan yg signifikan diantara ke dua klasifikasi retardasi mental ringan dan sedang. Hal itu kemungkinan sangat berpengaruh terhadap kemampuan kemamdirian anak retardasi mental dalam melakukan personal higyene sehari - hari.

Kemandirian anak retardasi mental yang dimaksud disini adalah kemandirian anak dalam melakukan keterampilan perawatan diri yang meliputi: Kebersihan badan, terdiri dari mencuci tangan, cuci muka, cuci kaki, sikat gigi, dan buang air kecil, makan dan minum, terdiri dari makan menggunakan tangan, makan menggunakan sendok, minum menggunakan cangkir, gelas, atausedotan, berpakaian, terdiri dari memakai pakaian dalam, memakai baju kaos,memakai celana/rok, memakai kemeja dan memakai kaos kaki serta sepatu, berhias, menolong diri, terdiri dari menghindari dan mengendalikan bahaya, komunikasi, terdiri dari aktivitas verbal dan non verbal. Keterampilan anak terkait hal tersebut tidak lepas dari upaya pendidikan secara keseluruhan dan pendidikan kesehatan pada khusunya, karena menjaga kebersihan pribadi secara optimal tidak mungkin dapat terwujud tanpa adanya penanaman sikap hidup bersih dan teladan dari orang tua, guru dan masyarakat sekitarnya (Hayati 2013).

Anak-anak berkebutuhan khusus biasanya kurang mampu dalam melakukan perawatan dirinya karena adanya ketidakmampuan dalam berinteraksi, komunikasi, dan perilaku. Hal tersebut dapat dioptimalkan dengan dilakukannya kemampuan bina diri adalah kecakapan atau ketrampilan diri untuk mengurus atau menolong diri sendiri dalam kehidupan sehari-hari sehingga tidak tergantung dengan orang lain Hayati (2008). 


\section{Simpulan}

\section{SIMPULAN DAN SARAN}

Faktor yang secara statistik terbukti berpengaruh terhadap tingkat kemandirian anak retardasi mental sedang adalah faktor usia dan tingkat pendidikan anak. Sedangkan faktor yang tidak berpengaruh terhadap kemadirian anak retardasi mental sedang yaitu faktor jenis kelamin dan urutan posisi anak. Dapat disimpulkan bahwa proses pendidikan dan kematangan usia dapat meningkatkan kemampuan bina diri anak retardasi mental, sehingga kemampuan anak dalamhal kecakapan atau ketrampilan diri untuk mengurus atau menolong diri sendiri dalam kehidupan sehari-hari semakin meningkat.

\section{Saran}

Memberikan motivasi pada anak retardasi mental untuk melakukan tugas sehari-hari dalam menjaga kebersihan diri mereka masing- masing tanpa bantuan orang lain dan memberikan motivasi orang tua untuk memberikan arahan pada anak retardasi mental untuk melakukan tugas sehari-hari dalam menjga kebersihan diri mereka masing- masing dengan cara memberi contoh pada mereka.

Sebagai referensi bagi peneliti selanjutnya untuk melakukan penelitian yang berhubungan dengan kemandirian anak retardasi mental dalam personal hygiene dan keterbatasan-keterbasan yang ada bisa di minimalisir oleh peneliti selanjutnya.

\section{DAFTAR PUSTAKA}

Arfandi. 2013. Kemandirian Perawatan Diri Pada Anak Retardasi Mental di SLB Negeri Ungaran. (online) Available from: htt://www.digilib.unimus.ac.id/download.php?id=9686. $\quad(20 \quad$ Pebruari 2016).

BKKBN. 2010. Kiat Praktis Keluarga dalam Pengasuhan dan Pengembangan Anak Usia Dini. Jakarta :Unicef Indonesia

Effendi, M. 2012. Pengantar psikopedagodik anak berkelainan. Jakarta: PT. Bumi Aksara

Meadow \& Simon, 2012. Lecture notes pediátrica. Jakarta: Erlangga

Nursalam. 2014. Konsep dan Penerapan Metodelogi Penelitian Ilmu Keperawatan. Edisi 2. Jakarta : Salemba Medika

Soetjiningsih. 2012. Tumbuh Kembang Anak. Cetakan Pertama, Jakarta : EGC.

Wong, D. L. 2008. Buku ajar keperawatan pediatrik (Agus Sutarna, Neti Juniarti, \& H.Y. Kuncara, penerjemah). Volume 1. Edisi 6. Jakarta: EGC Penerbit Buku Kedokteran 